\title{
Dinamika Perumusan Kebijakan Penataan Daerah Pemilihan Pada Pemilihan Umum Tahun 2019: Studi Kasus Kabupaten Kepulauan Selayar
}

\author{
Andi Ruslam Idrus1, Dwia Ariestina Pulubuhu², Gustiana A. Kambo \\ 1Program Studi Ilmu Politik, Universitas Hasanuddin, Indonesia. \\ E-mail: cullank.selayar@gmail.com \\ ${ }^{2}$ Program Studi Sosiologi, Fakultas Ilmu Sosial dan Ilmu Politik, Universitas Hasanuddin, Indonesia. \\ E-mail: dwiatn@yahoo.com \\ 3Program Studi Ilmu Politik, Fakultas Ilmu Sosial dan Ilmu Politik, Universitas Hasanuddin, Indonesia. \\ E-mail: gustianakambo@yahoo.com
}

\section{ARTICLE INFO}

Keywords: dynamism, electoral district, general election

Kata kunci: dinamika, daerah pemilihan, pemilihan umum

How to cite: Idrus, A. R., Pulubuhu, D. A., \& Kambo, G. A. (2019). Dinamika Perumusan Kebijakan Penataan Daerah Pemilihan pada Pemilihan Umum Tahun 2019: Studi Kasus Kabupaten Kepulauan Selayar. JAKPP (Jurnal Analisis Kebijakan dan Pelayanan Publik), 5(1), 125-143.

\section{ABSTRACT}

The implementation of the stages of electoral districts structuring for election in 2019 caused dissent and distrust expressed by the management of political parties in the Selayar Islands Regency to the general election commission of Selayar Islands who rejected the draft electoral districts (Dapil) changes for election in 2019. The change in the number of electoral districts also underlies the number of local politicians who are not progressing as candidates for the parliament of Selayar Islands because they think that the chances of small parties to obtain seats at the parliament regency will be very low. This study aims to determine the mechanism of structuring electoral districts in the implementation of general elections. The approach used in this study is a qualitative approach, the location of the study is the general election commission of Selayar Islands by conducting direct interviews with informants supported by secondary data. Data analysis method used is descriptive analysis. The results of this study indicate that the arrangement of electoral districts for the Parliament of Selayar Island in the 2019 as appropriate with the principles of electoral districts as elaborated in general election regulations as well as the technical guidelines for the arrangement of electoral districts for the parliament regency in 2019 Elections.

\footnotetext{
Abstrak

Pelaksanaan tahapan penataan daerah pemilihan untuk Pemilu Tahun 2019 menimbulkan perbedaan pendapat dan ketidakpercayaan yang diungkapkan oleh pengurus partai politik di Kabupaten Kepulauan Selayar kepada KPU Kabupaten Kepulauan Selayar yang menolak adanya rancangan perubahan Dapil pada Pemilu tahun 2019. Hal ini menimbulkan spekulasi bahwa KPU tidak profesional terkesan memaksakan perubahan Dapil tersebut. Perubahan jumlah Dapil ini pula yang mendasari banyaknya politisi lokal yang tidak maju sebagai calon anggota DPRD Kabupaten Kepulauan Selayar karena menganggap bahwa peluang partai-partai kecil untuk memperoleh kursi ditingkat DPRD Kab/Kota akan sangat kecil. Penelitian ini bertujuan untuk mengetahui mekanisme penataan daerah pemilihan pada pelaksanaan pemilihan umum. Pendekatan yang digunakan dalam penelitian ini adalah pendekatan kualitatif, lokasi penelitian adalah Kantor KPU Kabupaten Kepulauan Selayar dengan melakukan wawancara langsung dengan informan yang didukung oleh data skunder. Metode analisis data yang digunakan adalah deskriptif analisis. Hasil penelitian ini menunjukkan bahwa penataan daerah pemilihan untuk DPRD Kabupaten Kepulauan Selayar pada Pemilu tahun 2019 mengacu pada prinsip penataan Dapil sebagaimana dijabarkan dalam peraturan KPU serta Petujuk teknis
} 


\section{Pendahuluan}

Daerah pemilihan (Dapil) merupakan arena kompetisi politik yang sesungguhnya, sebab di sinilah partai politik dan calon anggota legislatif berebut suara pemilih untuk meraih kursi yang tersedia. Daerah pemilihan berfungsi membatasi jumlah anggota legislatif yang berasal dari daerah pemilihan tersebut, sehingga pemilih bisa mengenali dan berhubungan dengan mereka untuk menyampaikan aspirasinya secara lebih baik. Selain itu, fungsi lingkup daerah pemilihan dalam pemilihan umum anggota lembaga legislatif ialah (a) menjadi batas geografis penentu jumlah suara yang diperhitungkan untuk menentukan calon terpilih, dan (b) menentukan siapa yang diwakili oleh anggota lembaga legislatif dan karena itu juga menunjukkan siapa saja yang dapat meminta pertanggungjawaban kepada anggota lembaga legislatif.

Dalam sistem pemilu proporsional di mana kursi perwakilan yang tersedia adalah jamak (multi member constituency), isu pembentukan daerah pemilihan tidak hanya penentuan batas-batas wilayah tetapi juga jumlah kursi perwakilan yang disediakan atau besaran daerah pemilihan (district magnitude). Alokasi kursi ini juga digunakan sebagai dasar pengajuan calon oleh pimpinan partai politik dan penetapan calon terpilih anggota legislatif. Pilihan tentang lingkup dan besaran daerah pemilihan akan mempunyai implikasi yang sangat luas tidak saja pada derajat keterwakilan rakyat (proporsionalitas) dan akuntabilitas wakil rakyat tetapi juga pada sistem kepartaian dan sistem perwakilan rakyat yang akan terbentuk. Makin besar lingkup dan besaran daerah pemilihan makin tinggi derajat keterwakilan rakyat tetapi makin rendah derajat akuntabilitas wakil rakyat.

Penataan Dapil menjadi salah satu awal pelaksanaan tahapan Pemilu Tahun 2019 yang akan dilaksanakan serentak antara Pemilu Anggota DPR, DPD, dan DPRD dan Pemilu Presiden dan Wakil Presiden. Pasal 187 ayat (5) dan Pasal 189 ayat (5) UndangUndang Nomor 7 Tahun 2017 tentang Pemilihan Umum telah menetapkan Dapil untuk Pemilu Anggota DPR dan DPRD Provinsi sebagaimana tercantum dalam Lampiran III dan Lampiran IV Undang-Undang. Sedangkan sesuai dengan ketentuan Pasal 194 ayat (5) dan Pasal 195 ayat (1) dan ayat (2) Undang-Undang Nomor 7 Tahun 2017, penyusunan dan penetapan Dapil untuk Pemilu Anggota Anggota Dewan Perwakilan Rakyat Daerah (DPRD) Kabupaten/Kota dilakukan oleh Komisi Pemilihan Umum (KPU) dengan berkonsultasi kepada Dewan Perwakilan Rakyat Republik Indonesia (DPR RI). KPU RI kemudian menetapkan Peraturan KPU Nomor 16 Tahun 2017 tentang Penataan Daerah Pemilihan Anggota Dewan Perwakilan Rakyat Daerah Kabupaten/Kota dalam Pemilihan Umum Tahun 2019 untuk mengatur secara teknis mekanisme penataan Dapil tersebut.

Komisi Pemilihan Umum dalam Pemilu tahun 2019 ini telah menetapkan jumlah Dapil untuk Dewan Perwakilan Rakyat Daerah (DPRD) Kabupaten Kepulauan Selayar sebanyak 5 (lima) Dapil melalui Keputusan KPU Republik Indonesia Nomor 290/PL.01.3-Kpt/06/KPU/IV/2018 tentang penetapan daerah pemilihan dan alokasi 
kursi Anggota Dewan Perwakilan Rakyat Daerah Provinsi dan Dewan Perwakilan Rakyat Daerah Kabupaten/Kota di wilayah Provinsi Sulawesi Selatan dalam Pemiluhan Umum Tahun 2019.

Dari berbagai dinamika yang terjadi dalam proses pelaksanaan tahapan penataan Dapil pada Pemilu tahun 2019 maka peneliti tertarik melakukan penelitian mengenai bagaimana dinamika perumusan kebijakan daerah pemilihan Pemilihan umum tahun 2019 di Kabupaten Kepulauan Selayar. Penelitian ini bertujuan untuk mengetahui dan menganalisis dinamika perumusan kebijakan penataan daerah pemilihan DPRD Kabupaten Kepulauan Selayar pada Pemilihan Umum tahun 2019.

\section{Kajian Literatur}

\section{Pendekatan Institusional}

Scott (2008) dalam Villadsen (2011) dalam Ridha dan Basuki (2012) menjelaskan bahwa teori institusional digunakan untuk menjelaskan tindakan dan pengambilan keputusan dalam organisasi publik. Teori institusional berpendapat bahwa organisasi yang mengutamakan legitimasi akan memiliki kecenderungan untuk berusaha menyesuaikan diri pada harapan eksternal atau harapan sosial dimana organisasi berada. Penyesuaian pada harapan eksternal atau harapan sosial mengakibatkan timbulnya kecenderungan organisasi untuk memisahkan kegiatan internal mereka dan berfokus pada sistem yang sifatnya simbolis pada pihak eksternal (Meyer dan Rowan,1977).

Eksistensi organisasi terjadi pada cakupan organisasional yang luas dimana setiap organisasi saling mempengaruhi bentuk organisasi lainnya lewat proses institusionalisasi. Di Maggio dan Powell (1983) dalam Donaldson (1995) dalam Roen (2011), menyebutnya sebagai proses imitasi atau adopsi mimetic sebuah organisasi terhadap elemen organisasi lainnya. Menurut Di Maggio dan Powell (1983) dalam Donaldson (1995) dalam Roen (2011), organisasi terbentuk oleh lingkungan institusional yang ada di sekitar mereka. Ide-ide yang berpengaruh kemudian di institusionalkan dan dianggap sah dan diterima sebagai cara berpikir oleh organisasi tersebut.

Pendekatan ini memfokuskan institusi negara sebagai kajian utama, bagaimana organisasi institusi itu, apa tanggung jawab dari setiap perannya, dan bagaimana institusi itu berinteraksi (Marsh dan Stoker, 2002). Negara sebagai pusat kekuasaan (state power centre) merupakan inti dari pendekatan institusional. Fokus dari pendekatan ini adalah segi konstitusional dan yuridisnya. Bahasan tradisionalnya menyangkut undang-undang, kedaulatan, kedudukan kekuasaan formal serta yuridis dari lembagalembaga negara. Menurut Apter (1977) dalam Gani dan Cristiani (2014), Ada lima karakteristik atau pendekatan ini, yakni: Legalisme (legalism), strukturalisme, holistik (holism), sejarah atau (historicism) dan analisis normatif. 


\section{Metode Penelitian}

Penelitian ini dilaksanakan dengan memanfaatkan waktu penelitian selama 3 bulan yaitu pada bulan Juli sampai dengan bulan September tahun 2019. Pendekatan yang digunakan dalam penelitian ini adalah pendekatan kualitatif. Penelitian kualitatif merupakan metode penelitian yang digunakan pada kondisi obyek yang alamiah, dimana peneliti sebagai instrumen kunci, pengumpulan data dilakukan secara gabungan antara data melalui proses wawancara dengan dengan data sekunder, analisis data bersifat induktif dan hasil penelitian menekankan pada makna dari pada generalisasi. Objek penelitian ini adalah Komisi Pemilihan Umum Kabupaten Kepulauan Selayar. Kelembagaan KPU Kabupaten Kepulauan Selayar merupakan tempat bagi peneliti bekerja sebagai Aparatur Sipil Negara. Pelaksanaan penataan Dapil kerap melahirkan pendapat yang berbeda antara partai politik peserta pemilu dan masyarakat, untuk itu peneliti merasa perlu melakukan analisis terhadap mekanisme penataan Dapil apakah sudah sesuai regulasi yang berlaku atau belum sesuai dengan peraturan yang digunakan untuk penataan Dapil tersebut. Informan penelitian ini melibatkan 14 informan yaitu : 9 orang dari pengurus partai politik, 1 orang mantan Anggota KPU Kep. Selayar periode 2013-2018, 3 orang staf sekretariat KPU, dan 2 orang tokoh masyarakat.

\section{Hasil dan Pembahasan}

\section{Mekanisme Penataan Daerah Pemilihan DPRD Kabupaten Kepulauan Selayar Pada Pemilihan Umum Tahun 2019}

KPU Kabupaten Kepulauan Selayar dalam penyusunan daerah pemilihan DPRD Kabupaten/Kota mempunyai tugas dan wewenang untuk menata usulan Dapil dan alokasi kursi setiap Dapil Anggota DPRD Kabupaten/Kota dengan berpedoman pada prinsip sebagaimana diatur dalam ketentuan pasal 4 Peraturan Komisi Pemilihan Umum Nomor 16 Tahun 2017 tentang Penataan Daerah Pemilihan dan Alokasi Kursi Anggota DPRD Kabupaten/Kota Dalam Pemilihan Umum serta Keputusan KPU RI Nomor 18/PP.02-Kpt/03/KPU/I/2018 tentang Petunjuk Teknis penataan daerah pemilihan dan alokasi kursi DPRD Kabupaten/Kota dalam Pemilu. Pelaksanaan tahapan penataan Dapil untuk Pemilu tahun 2019 juga mengacu pada Peraturan KPU Nomor 7 tahun 2017 tentang Tahapan. Program dan Jadwal Penyelenggaraan Pemilu tahun 2019.

\section{a. Penyerahan Data Agregat Kependudukan Per Kecamatan}

Tahapan awal pelaksanaan penataan Dapil untuk tingkat Kabupaten/Kota yaitu KPU RI menerima Data Agregat Kependudukan per Kecamatan (DAK2) dari Kementerian Dalam Negeri Republik Indonesia pada tanggal 27 Novermber 2017. Jumlah penduduk Kabupaten Kepulauan Selayar berdasarkan DAK2 Pemilu tahun 2019 adalah sebesar 135.809 jiwa.

Menindaklanjuti serah terima DAK2 untuk Pemilu tahun 2019 tersebut KPU Kabupaten Kepulauan Selayar kemudian melakukan rapat koordinasi lintas sektoral pada tanggal 5 Januari 2019 bertempat di Aula kantor KPU 
Kabupaten Kepulauan Selayar yang dihadiri oleh perwakilan dari Badan Pusat Statistik (BPS) Kabupaten Kepulauan Selayar, Perwakilan dari Dinas Kependudukan dan Catatan Sipil Kabupaten Kepulauan Selayar, Badan Pemberdayaan Perempuan dan Keluarga Berencana (BP2KB) Kabupaten Kepulauan Selayar serta stakeholder pemerintah lainnya. Pertemuan tersebut dilakukan sebagai upaya mensinkronisasikan data kependudukan yang diserahkan oleh Kemendagri tersebut dengan data yang dimiliki oleh lembaga pemerintah lainnya yang juga melaksanakan pendataan penduduk berdasarkan lingkup kerja mereka masing-masing. Dalam rapat koordinasi tersebut ditemukan adanya perbedaan data kependudukan yang dimiliki oleh masing-masing instansi pemerintah tersebut. Perbedaan data kependudukan yang dimiliki oleh masing-masing instansi pemerintah tersebut dikarenakan perbedaan metode yang digunakan dalam pengumpulan data penduduk itu, namun perbedaan data tersebut tidak secara signifikan. Dari Hasil Rapat koordinasi tersebut, KPU Kabupaten kepulauan Selayar kemudian memutuskan untuk tetap menggunakan Data Agregat Kependudukan Per Kecamatan (DAK2) Untuk Kabupaten Kepulauan Selayar sebagai dasar untuk menentukan jumlah kursi DPRD Kab. Kepulauan Selayar yang akan digunakan pada Pemilu tahun 2019.

\section{b. Penetapan Jumlah Kursi DPRD Kabupaten/Kota}

Berdasarkan Data kependudukan dari Kemendagri kepada KPU RI serta berdasarkan hasil rapat koorodinasi yang dilaksanakan oleh KPU Kabupaten Kepulauan Selayar bersama perwakilan dari lembaga pemerintah pada tanggal 5 Januari 2019 tersebut maka KPU Kabupaten Kepulauan Selayar melaksanakan Rapat Pleno Terbuka Penetapan Jumlah Kursi Anggota DPRD Kabupaten Kepulauan Selayar tanggal 7 Januari 2018 bertempat di Kantor KPU Kabupaten Kepulauan Selayar. Rapat pleno terbuka tersebut dihadiri oleh sejumlah partai politik peserta Pemilu, perwakilan dari Pemerintah Kabupaten Kepulauan Selayar, perwakilan dari Forkopimda dan Bawaslu Kabupaten Kepulauan Selayar.

Keputusan tersebut dituangkan dalam Berita Acara KPU Kabupaten Kepulauan Selayar Nomor 04/PL.01.3-BA/7301/KPU-Kab/I/2018 dan Keputusan KPU Kabupaten Kepulauan Selayar Nomor 06/PL.01.3BA/7301/KPU-Kab/I/2018 tentang Penetapan Jumlah penduduk, Jumlah kursi DPRD dan Bilangan pembagi penduduk (BPPd) Kabupaten Kepulauan Selayar pada Pemilu tahun 2019. Jumlah penduduk Kabupaten Kepulauan Selayar sesuai keputusan tersebut adalah sebanyak 135.809 jiwa dengan alokasi kursi DPRD Kabupaten Kepulauan Selayar sebanyak 25 kursi, dan bilangan pembagi penduduk (BPPd) sebesar 5.432.

\section{c. Penyusunan Usulan Penataan Daerah Pemilihan}

Sesuai mekanisme penghitungan alokasi kursi dan tata kerja dalam penataan Dapil anggota Dewan Perwakilan Rakyat Daerah Kabupaten/Kota, 
dibuatlah 3 usulan berdasarkan simulasi daerah pemilihan. 3 usulan Dapil itu yaitu usulan 3 Dapil, usulan 4 Dapil dan usulan 5 Dapil.

Usulan 3 Dapil dipetakan dengan membagi Kecamatan yang ada di Kabupaten Kepulauan Selayar menjadi 3 Dapil yaitu Dapil Kepulauan Selayar 1 meliputi Kecamatan Benteng, Kecamatan Bontoharu dan Bontosikuyu, Dapil Kepulauan Selayar 2 meliputi Kecamatan Bontomatene, Buki dan Bontomanai, Dapil Kepulauan Selayar 3 meliputi Kecamatan Takabonerate, Pasimasunggu, Pasimasunggu Timur, Pasimarannu, dan Kecamatan Pasilambena. Usulan Dapil ini telah digunakan pada Pemilihan Umum Tahun 2014 lalu. Parpol yang mengusulkan 3 Dapil ini adalah Partai Nasdem, Partai Persatuan Pembangunan, Partai Kebangkitan Bangsa, Partai Keadilan Sejahtera, Partai Solidaritas Indonesia, dan Partai Garuda. Alasan partai politik itu mengusulkan opsi 3 Dapil yaitu untuk memberikan peluang yang sama bagi seluruh Parpol peserta pemilu agar dapat bersaing untuk memperebutkan suara pemilih di Dapil dengan kursi yang banyak. Usulan 3 Dapil juga akan mempertahankan kouta kursi sebanyak 9 kursi di kecamatan kepulauan sementara dengan usulan 4 dan 5 Dapil akan mengurangi 1 kursi di Kecamatan Kepulauan.

Sekretaris Partai Persatuan Pembangunan (PPP) Kabupaten Kepulauan Selayar, Winarsa Surung, S.H mengungkapkan sejumlah alasan sehingga mengusulkan opsi 3 Dapil. ${ }^{1}$

“......... Setelah kami melakukan pendalaman terkait opsi-opsi itu dengan pertimbangan bahwa untuk mendapatkan kursi bagi partai kami maka opsi 3 Dapil ini masih cocok digunakan untuk Pemilu 2019 ini. Pertimbangan kami saat itu yaitu bagaimana partai dapat memperoleh kursi di DPRD Kabupaten Kepulauan Selayar dengan mempertimbangkan bagaimana agar alokasi kursi itu bisa banyak disetiap Dapil. Prinsip dasar yang kita patuhi yaitu azas kesinambungan. Prinsip itu juga ada dalam aturan bahwa penyusunan Dapil itu harus memperhatikan agar alokasi kursi setiap Dapil itu bisa besar. Kedua PPP menganggap bahwa dengan kursi besar (alokasi kursi setiap Dapil) maka potensi partai kami untuk memperoleh kursi juga ikut besar pula. Ketiga bahwa partai kami berpandangan jika tetap 3 Dapil maka potensi kami menempatkan figur-figur kader disetiap Dapil juga akan semakin baik".

Usulan 4 Dapil dipetakan dengan membagi Kecamatan di Kabupaten Kepulauan Selayar menjadi 4 Dapil yaitu Dapil Kepulauan Selayar 1 meliputi Kecamatan Benteng, Bontoharu dan Kecamatan Bontosikuyu. Dapil Kepulauan Selayar 2 meliputi Kecamatan Bontomatene, Buki dan Bontomanai. Dapil Kepulauan Selayar 3 meliputi Kecamatan Pasimarannu dan Pasilambena. Dapil Kepulauan Selayar 4 meliputi Kecamatan Kecamatan Takabonerate, 
Pasimasunggu dan Pasimasunggu Timur. Usulan ini merupakan kombinasi dari usulan 3 Dapil dan usulan 5 Dapil. Usulan ini diajukan oleh kelompok masyarakat kepada KPU Kepulauan Selayar dalam berbagai kesempatan.

Usulan 5 Dapil dipetakan dengan membagi kecamatan di Kabupaten Kepulauan Selayar menjadi 5 Dapil yaitu Dapil Kepulauan Selayar 1 meliputi Kecamatan Benteng. Dapil Kepulauan Selayar 2 meliputi Kecamatan Bontomatene, Buki dan Bontomanai. Dapil Kepulauan Selayar 3 meliputi Kecamatan Pasimarannu, dan Pasilambena. Dapil Kepulauan Selayar 4 meliputi Kecamatan Kecamatan Takabonerate, Pasimasunggu, dan Pasimasunggu Timur. Dapil Kepulauan Selayar 5 meliputi Kecamatan Bontoharu dan Bontosikuyu. Parpol yang mengusulkan usulan 5 Dapil ini adalah partai Golkar, Partai Amanat Nasional dan Partai Bulan Bintang. Partai politik yang mengusulkan 5 Dapil ini mempertimbangkan letak geografis khususnya di 5 Kecamatan kepulauan yang terlalu besar sehingga berimplikasi pada biaya politik yang tinggi, waktu yang akan digunakan tergolong lama serta aspek kelompok suku minoritas yang belum terepresentasikan di DPRD Kabupaten Kepulauan Selayar.

Salah satu informan Bakhtiar Effendy, SH Ketua Bappilu Partai Golkar Kabupaten Kepulauan Selayar dalam wawancaranya mengatakan perlu pemekaran Dapil di wilayah kecamatan kepulauan yang dulunya 1 Dapil menjadi 2 Dapil. Hal ini dengan mempertimbangkan letak geografis dan cost politic. $^{2}$

"Khusus dikepulauan (kecamatan kepulauan) sebaiknya memang dipisah (menjadi 2 Dapil) jangan digabung karena letak geografis yang sangat berjauhan. Terdiri dari 5 Kecamatan yang berjauhan dan itu cost politic disitu yang sangat tinggi kalo tidak dipecah. Jadi diluar itu (kecamatan kepulauan) kalo sesuai jumlah penduduk yang jadi dasar kalo memang sudah cocok itu 2 Dapil yang perlu diperhatikan disitu keseimbangan masalah kursi di Dapil 3 itu. Dapil 3 itu (Kecamatan Pasilambena dan Kecamatan Pasimarannu) itu ada 3 kursi sementara Dapil 4 (Kecamatan Takabonerate, Kecamatan Pasimasunggu dan Pasimasunggu Timur) itu 5 kursi. Yang jelas di Kepulauan itu mesti 2 Dapil tidak bisa disatukan karena sangat jauh letak geografis dan biaya yang cukup tinggi bagi partai ya........".

\section{Analisis Prinsip Penataan Daerah Pemilihan Kabupaten Kepulauan Selayar}

Analisis menggunakan prinsip-prinsip penataan Dapil sebagaimana dapat dijabarkan sebagai berikut :

\section{a. Kesetaraan Nilai Suara}

\footnotetext{
2 Wawancara dengan Bakhtiar Effendy, S,H (Ketua Bappilu Partai Golkar Kab. Kep. Selayar) pada tanggal 8 Juli 2019
} 
Pada prinsip ini, kesetaraan nilai suara atau harga kursi yang setara antara suatu Dapil dengan Dapil yang lainnya adalah dengan memperhitungkan prinsip one man one vote one value. Penerapan prinsip ini dilakukan dengan cara menetapkan Bilangan Pembagi Penduduk (BPPd) Kabupaten Kepulauan Selayar. Melalui penggunaan BPPd, jumlah penduduk menjadi berbanding lurus dengan jumlah kursi yang diperoleh dan harga kursi antara satu Dapil dengan Dapil yang lainnya menjadi kurang lebih setara.

Mengenai kesetaraan nilai suara, peneliti melakukan pengkategorian terhadap tingkat kesetaraan menjadi 4 kategori yakni :

1) Sangat setara (ideal)

2) Setara

3) Tidak setara

4) Sangat tidak setara

Berdasarkan keempat kategori tersebut dengan berpedoman pada usulan Dapil terlihat bahwa nilai suara tertinggi terdapat pada usulan 5 Dapil yakni pada Dapil Kepulauan Selayar 5 dengan nilai suara 6.048, dan nilai suara terendah berada pada usulan 5 Dapil pada Dapil Kepulauan Selayar 2 dengan nilai 4.811 .

Berpedoman pada nilai suara terendah (4.811 suara) yang dihubungkan dengan 4 kategori nilai kesetaraan tersebut di atas, maka dapat ditetapkan bahwa untuk selisih suara $0 \mathrm{~s} / \mathrm{d} 1.203$ adalah kategori sangat setara, selisih suara $1.204 \mathrm{~s} / \mathrm{d} 2.406$ adalah kategori setara, selisih suara $2.407 \mathrm{~s} / \mathrm{d} 3.609$ adalah kategori tidak setara dan $3.610 \mathrm{~s} / \mathrm{d} 4.811$ adalah kategori sangat tidak setara.

Usulan 3 Dapil dengan nilai suara di Dapil Kepulauan Selayar 1 sebesar 5.777 suara, Dapil Kepulauan Selayar 2 sebesar 5.360 suara dan Dapil Kepulauan Selayar 3 sebanyak 5.284 suara maka selisih nilai suara terbanyak yakni 5.777 suara dengan nilai suara terendah yakni 5.284 suara adalah sebanyak 493 suara. Oleh karena itu untuk usulan 3 Dapil ini masuk dalam kategori sangat setara sehingga usulan 3 Dapil memenuhi prinsip ini.

Untuk usulan 4 Dapil dapat diuraikan bahwa selisih nilai suara terbanyak yakni pada Dapil Kepulauan Selayar 4 sebanyak 6.048 suara dan nilai suara terendah pada Dapil Kepulauan Selayar 3 sebanyak 4.901 suara, atau selisih sebanyak 1.147 suara. Dengan demikian usulan 4 Dapil dapat dimasukkan ke dalam kategori sangat setara sehingga usulan ini memenuhi prinsip kesetaraan nilai suara.

Pada usulan 5 Dapil bahwa selisih nilai suara terbanyak yaitu pada daerah pemilihan Kepulauan Selayar 5 sebanyak 6.048 suara dengan nilai suara terendah pada daerah pemilihan Kepulauan Selayar 2 sebanyak 4.811 suara, atau selisih sebanyak 1.237 suara. Dengan demikian usulan 5 daerah pemilihan 
dapat dimasukkan ke dalam kategori setara sehinggal usulan ini juga memenuhi prinsip kesetaraan nilai suara.

Dari hasil analisis tersebut diatas maka usulan 3 (tiga) Dapil dan usulan 4 Dapil merupakan opsi yang paling mendekati tingkat kesetaraan nilai yang paling tinggi dibanding usulan 5 Dapil. Dengan usulan 3 Dapil, khusus wilayah kepulauan akan mendapat porsi sebanyak 9 kursi sementara pada usulan 5 Dapil akumulasi wilayah kepulauan hanya akan mendapat jatah 8 kursi saja.

\section{b. Ketaatan pada Sistem Pemilu yang Proporsional}

Prinsip ketaatan pada sistem pemilu yang proporsional yaitu memperhatikan ketaatan dalam pembentukan Dapil dengan mengutamakan jumlah kursi yang besar agar presentase jumlah kursi yang diperoleh oleh setiap partai dapat setara dengan presentase suara sah yang diperolehnya. ${ }^{3}$ Prinsip ini mendorong agar setiap wilayah memiliki Dapil yang berkursi besar, diupayakan berada di interval 6 sampai 10 kursi. Hal ini dilakukan agar setiap partai politik mendapatkan distribusi kursi yang sama atau paling tidak mendekati, karena semakin besar alokasi kursi dapil maka akan semakin setara persentase perolehan kursi setiap partai.

Untuk prinsip ini, usulan 3 Dapil yang meliputi Dapil Kepulauan Selayar 1 dengan jumlah kursi sebanyak 6 kursi, Dapil Kepulauan Selayar 2 dengan jumlah kursi sebanyak 10 kursi dan Dapil Kepulauan Selayar 3 dengan jumlah kursi sebanyak 9 kursi, dapat memenuhi prinsip ini.

Pada usulan 4 Dapil, sebanyak 3 Dapil yaitu Kepulauan Selayar 1, Dapil Kepulauan Selayar 2 berada pada interval 6-10 kursi kecuali Dapil Kepulauan Selayar 3 dan Dapil Kepulauan Selayar 4 yang memiliki alokasi kursi dibawah interval 6 - 10 kursi, sehingga usulan 4 Dapil tidak dapat memenuhi pinsip ini.

Usulan 5 Dapil untuk Dapil Kepulauan Selayar 1 dan Kepulauan Selayar 3 masih berada pada interval 6 - 10 jumlah kursi, meskipun 3 Dapil lainnya yakni Kepulauan Selayar 2, Kepulauan Selayar 4 dan Kepulauan Selayar 5 berada di bawah interval 6 - 10 jumlah kursi, sehingga opsi 5 Dapil tidak memenuhi prinsip ini.

\section{c. Proporsionalitas}

Prinsip ini memperhatikan kesetaraan kursi antar Dapil untuk menjaga keseimbangan alokasi kursi. Dalam penyusunan Dapil diupayakan agar kesenjangan alokasi kursi setiap Dapil tidak terlalu jauh. ${ }^{4}$ Dari simulasi penataan Dapil dapat diketahui bahwa usulan 5 Dapil dapat memenuhi prinsip ini. Pada usulan 5 Daerah Pemilihan bahwa antara Dapil Kepulauan Selayar 1

\footnotetext{
${ }^{3}$ Keputusan KPU Nomor 18 Tahun 2017 tentang Petunjuk Teknis Penataan Daerah Pemilihan dan Alokasi Kursi Anggota DPRD Kabupaten/Kota dalam Pemilihan Umum 
dengan 4 Dapil yang lain mengalami perbedaan jumlah kursi pada setiap Dapilnya yang tidak terlalu besar, yaitu di Dapil Kepulauan Selayar 1 sebanyak 6 kursi dan Dapil Kepulauan Selayar 2 sebanyak 5 kursi, Dapil Kepulauan Selayar 3 sebanyak 6 kursi, Dapil Kepulauan Selayar 4 sebanyak 5 kursi serta Dapil kepulauan Selayar 5 sebanyak 3 kursi.

Pada usulan 4 daerah pemilihan, jumlah kursi pada pada Dapil Kepulauan Selayar 1 sebanyak 6 kursi, Dapil Kepulauan Selayar 2 sebanyak 10 kursi, Dapil Kepulauan Selayar 3 sebanyak 6 kursi, dan Dapil Kepulauan Selayar 4 sebanyak 3 kursi.

Pada usulan 3 Dapil terjadi kesenjangan jumlah kursi pada setiap Daerah Pemilihan, khususnya antara Kepulauan Selayar 2 (jumlah kursi 10) dengan Kepulauan Selayar 1 (jumlah kursi 6) terdapat selisih 4 kursi, begitupun dengan Kepulauan Selayar 3 (jumlah kursi 9) dan Kepulauan Selayar 2 (jumlah kursi 6) terjadi selisih 3 kursi. Sehingga untuk pilihan usulan 3 dan usulan 4 Dapil ini tidak memenuhi prinsip proporsionalitas.

\section{d. Integritas Wilayah}

Prinsip integritas wilayah memperhatikan keutuhan dan keterpaduan wilayah, kondisi geografis, sarana perhubungan dan aspek kemudahan transportasi dalam menyusun beberapa daerah kecamatan ke dalam sebuah Dapil.

Berdasarkan data Badan Pusat Statistik dalam Selayar Dalam Angka tahun 2018, Kabupaten Kepulauan Selayar memiliki luas wilayah daratan seluas 1.357,03 km2. Dengan kondisi geografis yang ada, Kecamatan Pasilambena merupakan kecamatan terjauh yang berjarak $+193 \mathrm{~km}$ dari ibukota kabupaten Kepulauan Selayar. 11 kecamatan yang ada di Kabupaten Kepulauan Selayar tersebut secara geografis terbagi menjadi 2 wilayah, yaitu untuk wilayah daratan yaitu Kecamatan Bontomatene, Buki, Bontomanai, Benteng, Bontoharu dan Bontosikuyu dan untuk wilayah kepulauan yaitu Kecamatan Pasilambena, Pasimarannu, Pasimasunggu, Pasimasunggu Timur, dan Kecamatan Taka Bonerate. Memperhatikan keutuhan dan keterpaduan wilayah dan kondisi geografis kecamatan daratan dan kecamatan kepulauan, maka tidak memungkinkan untuk menggabungkan kecamatan daratan dan kecamatan kepulauan.

Sarana perhubungan untuk wilayah daratan dapat diakses dengan mudah melalui jalur darat dengan moda kendaraan seperti mobil dan motor sedangkan untuk wilayah kepulauan hanya dapat diakses melalui jalur transportasi laut sehingga banyak waktu yang diluangkan untuk mencapai kelima kecamatan kepulauan tersebut. Keberadaan transporasi laut dengan menggunakan perahu motor/kapal kayu bermesin juga masih tersedia hingga saat ini dengan biaya sewa kapal yang cukup mahal.

Berdasarkan pertimbangan ini, maka diperlukan adanya pembagian 2 Dapil dalam wilayah kepulauan yaitu 1 Dapil untuk Kecamatan Pasilambena dan Kecamatan Pasimarannu, dan 1 Dapil lainnya untuk Kecamatan 
Pasimasunggu, Pasimasunggu Timur dan Kecamatan Taka Bonerate. Penggabungan wilayah kecamatan dalam 2 Dapil di kepulauan ini adalah berdasarkan kondisi geografis dimana Kecamatan Pasimarannu dan Kecamatan Pasilambena berada dalam 1 wilayah yang berdekatan dan terjauh dari 3 kecamatan lainnya. Hal ini menjadi pertimbangan untuk dilakukan analisis oleh KPU Kabupaten Kepulauan Selayar untuk dilakukan pemekaran Dapil khususnya diwilayah kecamatan kepulauan.

\section{e. Berada Dalam 1 Wilayah yang Sama}

Kabupaten Kepulauan Selayar merupakan satu di antara 24 Kabupaten/Kota di Sulawesi Selatan yang letaknya di ujung selatan Pulau Sulawesi yang wilayah daratannya terpisah dengan pulau Sulawesi. Kabupaten ini terdiri dari gugusan pulau sehingga membentuk suatu wilayah kepulauan.

Undang-Undang Nomor 7 tahun 2017 tentang Pemilihan Umum sesuai lampiran II yang menjadi satu kesatuan dalam regulasi tersebut telah menegaskan bahwa untuk Daerah Pemilihan Anggota DPRD Provinsi Sulawesi Selatan, Kabupaten Kepulauan Selayar dimasukkan dalam Dapil Sulsel 4 dengan jumlah kursi sebanyak 7 kursi dengan wilayah yang terdiri dari Kabupaten Kepulauan Selayar, Kabupaten Bantaeng dan Kabupaten Jeneponto.

\section{f. Kohesivitas}

Prinsip Kohesivitas yang dimaksud di sini adalah dalam penyusunan Dapil, perlu memperhatikan unsur sejarah, kondisi sosial budaya, adat istiadat dan kelompok minoritas. ${ }^{5}$ Sosial budaya serta adat istiadat masyarakat yang bermukim di Kabupaten Kepulauan Selayar hampir sama antara wilayah yang satu dengan wilayah yang lainnya. Hal ini dipengaruhi oleh persamaan suku dan agama yang dianut oleh mayoritas masyarakat, baik di wilayah daratan maupun di wilayah kepulauan di Kabupaten Kepulauan Selayar.

Wilayah daratan pulau Selayar dihuni oleh sebagian besar dari suku Makassar dan Bugis. Untuk wilayah kepulauan, selain suku Bugis dan Makassar yang menaungi hampir seluruh wilayah kepulauan, mereka hidup berdampingan dengan suku Bajo dan suku Buton yang juga telah bermukim dan menyebar hidup berkelompok di seluruh wilayah kepulauan.

Pemeluk agama di Kabupaten Kepulauan Selayar didominasi oleh pemeluk agama Islam. Data Badan Pusat Statistik tahun 2017 menunjukkan bahwa jumlah penduduk yang memeluk agama Islam di Kabupaten Kepulauan Selayar sebanyak 186.395 jiwa. Penduduk yang memeluk agama Kristen Protestan sebanyak 534 jiwa, pemeluk agama Katolik sebanyak 385 
jiwa, pemeluk agama Hindu sebanyak 298 jiwa dan agama Budha sebanyak 7 Jiwa.

Keterwakilan kelompok minoritas dalam komposisi caleg terpilih pada lembaga DPRD Kabupaten Kepulauan Selayar masih tergolong sangat kecil. Dari sisi kelompok keagamaan, caleg terpilih pada Pemilu tahun 2019 tidak satupun pemeluk agama lain selain Islam. Dari sisi etnitas, sebagian besar caleg terpilih pada Pemilu tahun 2019 ini merupakan representase dari etnis Bugis, Makassar dan Buton, sementara etnis Bajo tidak memiliki caleg terpilih dari sukunya sendiri. H. Rakhmat Zaenal, Lc menilai penataan Dapil perlu memperhatikan sisi sosial budaya masyarakat. ${ }^{6}$

“......Saat itu ada 2 point yang saya sampaikan bahwa semakin banyak Dapil maka semakin dekat seorang wakil rakyat dengan masyarakat yang diwakilinya. Dalam tatanan sosial masyarakat Selayar, Selayar ini terdiri dari banyak suku ada Buton, Bugis, Bajo, Makassar dan beberapa suku lainnya sehingga saat itu saya terkesan dengan apa yang disebut etnik demokrasi. Selama ini setiap kita berbicara tentang demokrasi keterwakilan maka masyarakat memilih orang sebagai presentasi dari masyarakat itu. Fakta selama ini, ketika ada wakilnya tetapi dari etnik yang berbeda maka yang diperhatikan etniknya saja sehingga ini berpengaruh pada etnik yang komunitasnya lebih kecil sepertinya kurang terwakili. Sebagai contoh misalnya selama ini belum pernah ada wakil rakyat dari etnik Bajo atau dari entik Buton yang mendiami wilayah Kecamatan Pasimarannu dan Kecamatan Pasilambena. Begitupun di wilayah Kecamatan Takabonerate, sekalipun suku Bajo banyak mendiami pulau-pulau dalam wilayah kecamatan Takabonerate tetapi sepertinya belum terwakili sehingga ini yang menyebabkan selama ini etnik mayoritas yang mendominasi kekuasaan sehingga keterwakilan dari etnik etnik yang minoritas ini menjadi sangat kecil. ....".

Dari prinsip ini dapat diketahui bahwa hanya Usulan 5 Dapil yang memenuhi syarat dibandingkan 2 usulan lainnya.

\section{g. Kesinambungan}

Peraturan KPU Nomor 16 tahun 2017 menjelaskan bahwa penyusunan Dapil memperhatikan penetapan Dapil pada Pemilu terakhir, kecuali terjadi perubahan jumlah penduduk yang mengakibatkan alokasi kursi dalam 1 Dapil melebihi batas maksimal dan/atau kurang dari batas minimal, adanya pemekaran wilayah, dan Dapil yang telah disusun bertentangan dengan prinsip penataan Dapil. Dari penjelasan ini maka hanya usulan 3 Dapil yang memenuhi prinsip ini. 
Dari keseluruhan uraian prinsip penataan Dapil diatas dapat diketahui bahwa usulan 3 Dapil dan Usulan 5 Dapil memiliki bobot yang sama yaitu masing-masing memiliki 5 point atas pemenuhan prinsip-prinsip penataan daerah pemilihan, kecuali usulan 4 Dapil yang hanya memiliki 4 point yang dapat memenuhi prinsip-prinsip penataan Dapil tersebut.

Tabel 1 Kesesuaian dan Ketidak Sesuaian Prinsip Penataan Dapil dari Setiap Usulan Dapil

\begin{tabular}{|l|c|c|c|}
\hline \multicolumn{1}{|c|}{ Prinsip Penataan Dapil } & 3 Dapil & $\mathbf{4}$ Dapil & $\mathbf{5}$ Dapil \\
\hline Kesetaraan Nilai Suara & Terpenuhi & Terpenuhi & Terpenuhi \\
\hline $\begin{array}{l}\text { Ketaatan pada Sistem Pemilu yang } \\
\text { Proporsional }\end{array}$ & Terpenuhi & $\begin{array}{c}\text { Tidak } \\
\text { Terpenuhi }\end{array}$ & $\begin{array}{c}\text { Tidak } \\
\text { Terpenuhi }\end{array}$ \\
\hline Proporsionalitas & $\begin{array}{c}\text { Tidak } \\
\text { Terpenuhi }\end{array}$ & $\begin{array}{c}\text { Tidak } \\
\text { Terpenuhi }\end{array}$ & Terpenuhi \\
\hline Integritas Wilayah & Terpenuhi & Terpenuhi & Terpenuhi \\
\hline Berada dalam Wilayah yang Sama & Terpenuhi & Terpenuhi & Terpenuhi \\
\hline Kohesivitas & Terpenuhi & Terpenuhi & Terpenuhi \\
\hline Kesinambungan & Terpenuhi & $\begin{array}{c}\text { Tidak } \\
\text { Terpenuhi }\end{array}$ & $\begin{array}{c}\text { Tidak } \\
\text { Terpenuhi }\end{array}$ \\
\hline Bobot & $\mathbf{5}$ & $\mathbf{4}$ & $\mathbf{5}$ \\
\hline
\end{tabular}

\section{Implikasi Teori}

Penataan daerah pemilihan di Kabupaten Kepulauan Selayar mengacuh pada data kependudukan dari Kemendagri serta berdasarkan hasil rapat koordinasi yang dilaksanakan oleh KPU Kabupaten Kepulauan Selayar bersama perwakilan dari lembaga pemerintah. Tahapan ini dimulai pada proses sosialisasi terkait bagimana mekanisme dan aturan dalam pelaksanaan daerah pemilihan dan KPU Kepulauan selayar melibatkan berbagai elemen tokoh masyarakat terkhusus pada masayarakat yang ada di Kabupaten Kepulauan Selayar dengan tujuan untuk merumuskan dan memetakan usulan-usulan penataan daerah pemilihan.

Tahapan yang dilakukan KPU melihat aspek kondisi masyarakat yang ada di Kabupaten Kepulauan Selayar menjadi pertimbangan untuk dilakukan penataan ulang Dapil dari 3 Dapil pada Pemilu tahun 2014 kemudian diubah menjadi 5 Dapil pada Pemilu tahun 2019.

Kondisi geografis yang ada tidak memungkinkan untuk menyatuhkan kecamatan daratan dan di kecamatan kepulauan disebabkan akses yang berbeda akan mempersulit calon anggota legislatif dalam pemetaan untuk mendapatkan suara. Disamping kondisi geografis, kondisi sosial budaya masyarakat perlu menjadi perhatian agar penyatuan wilayah dalam satu kesatuan Dapil dapat terintegrasi dengan baik. Atas pertimbangan 
tersebut maka penyelenggara Pemilu menganggap perlu adanya penataan ulang kembali terkait Dapil. Dengan pertimbangan semakin banyak daerah pemilihan maka semakin dekat masyarakat dengan wakilnya yang ada di parlemen sehingga diharapkan terjalin komunikasi dan interaksi yang baik antara masyarakat dengan wakil rakyat di Dapil tersebut.

Kondisi masyarakat Kabupaten Kepulauan Selayar tergolong masyarakat yang beragam yang terdiri dari berbagai macam suku yaitu, suku Buton, Bugis, Bajo dan Makassar dan beberapa suku lainnya sehingga alasan inilah menjadi dasar acuan dalam perubahan daerah pemilihan.

Hal ini sejalan dengan teori yang dikemukakan oleh Meyer dan Scott (1983) dalam Donaldson (1995) dalam Ferry Roen (2011) yang mengklaim bahwa organisasi berada di bawah tekanan sosial guna melengkapi dan menyelaraskan sebuah struktur. Organisasi harus melakukan kompromi dan memelihara struktur operasional secara terpisah kerena struktur organisasi tidak ditentukan oleh situasi lingkungan tugas, tetapi lebih dipengaruhi oleh situasi masyarakat secara umum di mana sebuah organisasi dibentuk. Langkah yang diambil KPU sebagai bentuk rasionalitas terhadap masyarakat bahwa ketika memperkecil Dapil maka hubungan kontituen dengan para wakil rakyat akan merasa dekat karena jangkauan wilayah yang tidak luas.

Menurut Apter (1977) dalam Gani dan Cristiani (2014), berdasarkan pendekatan dalam institusionalisme ada lima karakteristik dalam kajian utama yaitu :

1. Legalisme, yang mengkaji aspek hukum untuk menilai proses dan keputusan yang dihasilkan oleh sebuah lembaga/organisasi. Tahapan pelaksanaan kegiatan penataan Dapil berpedoman pada PKPU Nomor 7 tahun 2017 tentang Tahapan, program dan jadwal penyelenggaraan Pemilu tahun 2019. Mekanisme pelaksanaan kegiatannya juga mempedomani UU Nomor 7 Tahun 2017 tentang Penyelenggaraan Pemilihan Umum, PKPU Nomor 16 Tahun 2017 tentang Penataan Dapil dan Alokasi Kursi Anggota DPRDKabupaten/Kota dalam Pemilu, serta Keputusan KPU Nomor 18/PP.02-Kpt/03/KPU/I/2018 tentang Petunjuk Teknis Penataan Dapil dan Alokasi Kursi DPRD Kabupaten/Kota dalam Pemilu serta surat edaran lainnya yang dikeluarkan oleh KPU RI dan KPU di tingkat Provinsi.

2. Strukturalisme, yaitu menekankan pada perangkat kelembagaan utama atau menekankan pentingnya keberadaan struktur dan struktur itu pun dapat menentukan perilaku seseorang. Pada pendekatan ini kelembagaan KPU telah melaksanakan fungsi sesuai kewenangan yang dimiliki dari masing-masing jenjang struktur yang ada sebagaimana telah diamanatkan dalam peraturan perundang-undangan yang berlaku. KPU tingkat Kabupaten dan Kota memiliki wewenang dalam merumuskan usulan Dapil dengan mempertimbangkan masukan dari berbagai pihak kemudian mengusulkan kepada KPU RI dan melakukan kajian bersama dengan KPU ditingkat Provinsi dalam bentuk monitoring dan supervisi terhadap seluruh usulan yang diajukan oleh jajaran KPU Kabupaten/Kota dalam wilayah administrasinya sehingga keputusan yang 
dikeluarkan oleh KPU RI nantinya dapat diterima sebagai keputusan yang ideal dan dapat diterima oleh semua pihak.

3. Holistik, menekankan pada kajian sistem yang menyeluruh dalam artian lembaga eksekutif, legislatif maupun yudikatif digunakan dalam pengkonsepan idealnya. Proses pengkajian yang dilakukan tidak hanya mengedepankan kajian yuridis saja, KPU juga telah melakukan beberapa kegiatan dalam rangka menerima masukan dari berbagai pihak untuk melihat dari berbagai aspek terhadap setiap usulan daerah pemilihan yang disusun tersebut. Kegiatan tersebut dalam bentuk Rapat kerja dan uji publik dengan melibatkan seluruh komponen yaitu Forkopimda, Pemda, Parpol peserta Pemilu, tokoh masyarakat, LSM dan tokoh kepemudaan.

4. Sejarah atau Historicism yang menekankan pada analisisnya dalam aspek sejarah seperti dalam kehidupan sosial, ekonomi dan kebudayaan. Prinsip penataan daerah pemilihan yaitu prinsip kohesivitas menggunakan pendekatan ini. Kondisi sosial, budaya, adat istiadat serta kelompok minoritas masyarakat menjadi perhatian penting dalam penyusunan usulan Dapil. Pemekaran Dapil di wilayah kepulauan yang pada Pemilu tahun 2014 lalu diakumulasikan menjadi 1 Dapil kemudian pada usulan 5 Dapil (Pemilu 2019) dipecah menjadi 2 wilayah Dapil serta 1 Dapil untuk Ibukota Kabupaten berdiri sendiri sebagai 1 Dapil mendasari kajian dengan memperhatikan kondisi sosial, ekonomi, budaya serta adat istiadat dari wilayah-wilayah tersebut. Aspek sejarah dalam penataan Dapil menjadi salah satu pertimbangan agar dapil yang dibentuk dapat merefleksikan refresentase keterwakilan antar suku. Hasil Pemilu tahun 2014, belum dapat dikatakan sebagai hasil yang telah mengakomodir kelompok minoritas yang ada khususnya di wilayah kecamatan kepulauan. Hasil Pemilu tahun 2014 hanya mengakomodasi suku mayoritas yang mendominasi kekuasaan sehingga keterwakilan dari etnik minoritas sangat kecil. Dari sisi aksebilitas, jarak tempuh antara pulau yang satu dengan yang lainnya memiliki jarak yang berjauhan menjadi hambatan para calon anggota legislatif (caleg) dalam melakukan sosialisasi, hal tersebut berpengaruh pada biaya politik yang tinggi. Pada aspek budaya politik, terhambatnya pendidikan politik baik dari partai politik maupun dari penyelenggara pemilu menjadi aspek terpenting sehingga mempengaruhi perilaku pemilih.

5. Analisis Normatif atau normati Analisis merupakan analisis yang menekankan analisisnya dalam aspek yang normatif sehingga akan terfokus pada penciptaan good government. Salah satu tujuan dilakukannya pemekaran Dapil Kabupaten Kepulauan Selayar untuk memberikan akses antara wakil rakyat dengan yang diwakili mengingat kondisi yang ada di Kabupaten Kepulauan Selayar terbagi dari wilayah kepulauan dan wilayah daratan, yang artinya wakil rakyat lebih mudah membangun komunikasi dengan masyarakat karena jangkauanya tidak terlalu luas, dibandingkan dengan 3 Dapil akan lebih efisien dengan 5 Dapil sehingga ada sinergi antara masyarakat dengan wakil rakyat dan pemerintah agar terciptanya pemerintahan yang baik. 


\section{Kesimpulan}

Penetapan 5 Dapil DPRD Kabupaten Kepulauan Selayar pada Pemilu tahun 2019 telah disusun sesuai dengan peraturan perundang-undangan yang berlaku. Hal tersebut mengacu pada Peraturan Komisi Pemilihan Umum Nomor 16 tahun 2017 tentang Penataan Daerah Pemilihan Dan Alokasi Kursi Anggota Dewan Perwakilan Rakyat Daerah Kabupaten/Kota dalam Pemilu serta Keputusan Komisi Pemilihan Umum Nomor 18/PP.02-Kpt/03/1/2018 Tentang Petunjuk Teknis Penataan Dapil Dan Alokasi Kursi DPRD Kabupaten/Kota. KPU Kabupaten Kepulauan Selayar melaksanakan penataan Dapil dengan mengacu pada tahapan, program dan jadwal Pemilu tahun 2019. KPU Kabupaten Kepulauan Selayar juga melaksanakan penataan Dapil dengan mengacu prinsip penataan Dapil.

1. Kesetaraan Nilai Suara

Pada prinsip ini, kesetaraan nilai suara atau harga kursi yang setara antara suatu Dapil dengan Dapil yang lainnya adalah dengan memperhitungkan prinsip one man one vote one value (satu orang satu suara satu nilai). Dari hasil analisis bahwa usulan 3 Dapil, usulan 4 Dapil serta usulan 5 Dapil memenuhi prinsip ini.

2. Ketaatan Pada Sistem pemilu Yang Proporsional

Prinsip ketaatan pada sistem pemilu yang proporsional yaitu memperhatikan ketaatan dalam pembentukan Dapil dengan mengutamakan jumlah kursi yang besar agar presentase jumlah kursi yang diperoleh oleh setiap partai politik dapat setara dengan presentase suara sah yang diperolehnya. Prinsip ini mendorong agar setiap wilayah memiliki Dapil yang berkursi besar, diupayakan berada di interval 6 (enam) sampai 10 (sepuluh) kursi. Hal ini dilakukan agar setiap partai politik mendapatkan distribusi kursi yang sama atau paling tidak mendekati, karena semakin besar alokasi kursi dapil maka akan semakin setara persentase perolehan kursi setiap partai.

Usulan 3 Dapil yang meliputi Dapil Kepulauan Selayar 1 dengan jumlah kursi sebanyak 6 kursi, Dapil Kepulauan Selayar 2 dengan jumlah kursi sebanyak 10 kursi dan Dapil Kepulauan Selayar 3 dengan jumlah kursi sebanyak 9 (Sembilan) kursi, dapat memenuhi prinsip ini, sementara usulan 4 dan usulan 5 Dapil tidak memenuhi prinsip ini.

3. Proporsionalitas

Prinsip ini memperhatikan kesetaraan kursi antar Dapil untuk menjaga keseimbangan alokasi kursi. Dalam penyusunan Dapil diupayakan agar kesenjangan alokasi kursi setiap Dapil tidak terlalu jauh. Dari simulasi penataan Dapil dapat diketahui bahwa usulan 5 (lima) Dapil dapat memenuhi prinsip ini.

4. Integritas Wilayah

Dalam Penataan Dapil berdasarkan prinsip integritas wilayah sesuai Peraturan KPU Nomor 16 tahun 2017 dijelaskan bahwa prinsip integritas wilayah, yaitu memperhatikan keutuhan dan keterpaduan wilayah, kondisi 
geografis, sarana perhubungan dan aspek kemudahan transportasi dalam menyusun beberapa daerah kecamatan ke dalam sebuah daerah pemilihan. Berdasarkan pertimbangan akan sarana transportasi, diperlukan adanya pembagian 2 Dapil di wilayah kepulauan yaitu 1 Dapil untuk Kecamatan Pasilambena dan Kecamatan Pasimarannu, dan 1 Dapil lainnya untuk Kecamatan Pasimasunggu, Pasimasunggu Timur dan Kecamatan Taka Bonerate. Dari hasil analisis maka usulan 4 Dapil dan usulan 5 Dapil memenuhi prinsip ini.

5. Berada Dalam Wilayah Yang sama

Prinsip berada dalam satu wilayah yang sama yaitu penyusunan Dapil Anggota DPRD Kabupaten/Kota harus tercakup seluruhnya dalam suatu Dapil Anggota DPRD Provinsi. Pelanggaran terhadap implementasi prinsip berada dalam satu wilayah yang sama berpotensi terjadi untuk wilayah yang menggunakan bagian kabupaten/kota atau kecamatan sebagai dasar penyusunan Dapil Anggota DPRD Provinsi. Undang-Undang Nomor 7 tahun 2017 tentang Pemilu sesuai lampiran II yang menjadi satu kesatuan dalam regulasi tersebut telah menegaskan bahwa untuk Dapil Anggota DPRD Provinsi Sulawesi Selatan, Kabupaten Kepulauan Selayar dimasukkan dalam Dapil Sulsel 4 dengan jumlah kursi sebanyak 7 kursi dengan wilayah yang terdiri dari Kabupaten Kepulauan Selayar, Kabupaten Bantaeng dan Kabupaten Jeneponto. Hal dapat disimpulkan bahwa dari ketiga usulan penataan Dapil yang disusun oleh KPU Kabupaten Kepulauan Selayar telah sesuai dengan prinsip berada dalam satu wilayah yang sama.

6. Kohesivitas

Prinsip Kohesivitas yang dimaksud di sini adalah dalam penyusunan Dapil, perlu memperhatikan unsur sejarah, kondisi sosial budaya, adat istiadat dan kelompok minoritas. Hasil analisis menunjukkan bahwa ketiga usulan Dapil tersebut telah memenuhi prinsip ini.

7. Kesinambungan

Prinsip kesinambungan, yaitu penyusunan Dapil dilakukan dengan memperhatikan Dapil yang sudah ada pada Pemilu terakhir. Dengan demikian, perubahan terhadap Dapil diusahakan dilakukan seminimal mungkin. Dari hasil analisis dengan menggunakan prinsip ini maka usulan 3 Dapil memenuhi prinsip ini.

Seara keseluruhan berdasarkan ketujuh prinsip penataan Dapil maka usulan 3 Dapil dan usulan 5 Dapil memiliki bobot yang sama yaitu sebesar 5 point sementra usulan 4 Dapil hanya memiliki 4 point. Penataan daerah pemilihan tergantung pada prinsip-prinsip dan tujuan yang digariskan oleh undang-undang dan peraturan yang ada sesuai instrument yang ditetapkan, tetapi sebagai salah satu proses demokrasi, yang juga tak kalah pentingnya untuk diperhatikan adalah target dan nilai luhur demokrasi itu sendiri, terutama proporsional hasil dan keterwakilan yang lebih nyata dalam memperkuat legitimasi wakil yang antara lain dengan lebih mendekatkan jarak antara pemilih dan wakilnya. Penataan daerah diharapkan juga bisa mendukung penguatan 
sistem kepartaian yang lebih mengakar, yang sekaligus untuk tujuan pemerintahan yang lebih efektif.

Pelaksanaan tahapan penataan daerah pemilihan sebagaimana telah dijalankan oleh KPU Kabupaten Kepulauan Selayar berdasarkan uraian dan analisis dapat disimpulkan bahwa KPU Kabupaten Kepulauan Selayar telah menjalankan tahapan dan mekanisme sesuai dengan peraturan perundang-undangan yang berlaku. Analisis yang digunakan juga telah memenuhi prinsip dasar dari penataan daerah pemilihan.

\section{Persantunan}

Ucapan terima kasih penulis ucapkan untuk kedua orang tua penulis, terima kasih untuk setiap perjuangan dan juga do'a dari orang tua penulis dalam penyusunan jurnal ini. Penulis dengan segala kerendahan hari menyadari bahwa penyusunan penelitian ini dapat disusun dengan baik karena adanya dorongan dan bantuan dari berbagai pihak, oleh karena itu pada kesempatan ini penulis menyampaikan rasa terima kasih kepada : Prof. Dr. Dwia Aries Tina Pulubuhu, MA selaku pembimbing I dan Dr. Gustiana A. Kambo, S.IP., M.Si selaku Pembimbing II yang telah memberikan arahan dan masukan selama proses penyusunan penelitian ini, serta semua pihak yang telah me

\section{Daftar Pustaka}

Badan Pusat Statistik (BPS) Kabupaten Kepulauan Selayar, 2019. Selayar Dalam Angka Tahun 2018.

Gani E, Cristiani, W. 2014. Pendekatan Kelembagaan Dalam Ilmu Politik. Universitas Indonesia.

Keputusan KPU Nomor 18 Tahun 2017 tentang Petunjuk Teknis Penataan Daerah Pemilihan dan Alokasi Kursi Anggota DPRD Kabupaten/Kota dalam Pemilihan Umum.

Keputusan KPU Republik Indonesia Nomor 290/PL.01.3-Kpt/06/KPU/IV/2018 tentang penetapan daerah pemilihan dan alokasi kursi Anggota Dewan Perwakilan Rakyat Daerah Provinsi dan Dewan Perwakilan Rakyat Daerah Kabupaten/Kota di wilayah Provinsi Sulawesi Selatan dalam Pemilu Tahun 2019.

Keputusan KPU Kabupaten Kepulauan Selayar Nomor 06/PL.01.3-BA/7301/KPU$\mathrm{Kab} / \mathrm{I} / 2018$ tentang Penetapan Jumlah penduduk, Jumlah kursi DPRD dan Bilangan pembagi penduduk (BPPd) Kabupaten Kepulauan Selayar pada Pemilu Tahun 2019.

Marsh, D and Stoker, G. 2002. Teori dan Metode Dalam Ilmu Politik, terj, New York, Palgrave MacMillan.

Meyer, J. dan B. Rowan, 1977. Institutionalized Organizations Formal Structure as Myth and Ceremony. The American Journal of Sociology.

Peraturan KPU Nomor 16 Tahun 2017 Tentang Penataan Daerah Pemilihan dan Alokasi Kursi Anggota DPRD Kabupaten/Kota Dalam Pemilihan Umum. 
Ridha M, Basuki, H. Pengaruh Tekanan Eksternal, Ketidakpastian Lingkungan, dan Komitmen Managemen Terhadap Penerapan Transparansi Laporan Keuangan. Jurnal 046-ASPAK-06. http://sna.akuntansi.unikal.ac.id.

Roen, F, 2011. “Teori Institusional", perilakuorganisasi.com. Diakses tanggal 13 November 2019.

Undang-Undang Nomor 7 Tahun 2017 tentang Pemilihan Umum 